\title{
Preferences for sunflower oil produced conventionally, produced with nanotechnology or genetically modified in the Araucanía Region of Chile
}

\author{
Berta Schnettler ${ }^{1}$, Gloria Crisóstomo ${ }^{1}$, Natally Mills ${ }^{1}$, Horacio Miranda ${ }^{1}$, \\ Marcos Mora ${ }^{2}$, Germán Lobos ${ }^{3}$, and Klaus G. Grunert ${ }^{4}$ \\ ${ }^{1}$ Facultad de Ciencias Agropecuarias y Forestales, Universidad de La Frontera. Casilla 54-D, Temuco, Chile. \\ ${ }^{2}$ Facultad de Ciencias Agronómicas, Universidad de Chile. Avda. Santa Rosa \#11315, La Pintana, Santiago, \\ Chile. \\ ${ }^{3}$ Facultad de Ciencias Empresariales, Universidad de Talca, 2 Norte 685, Talca, Chile. \\ ${ }^{4}$ MAPP Centre for Research on Customer Relations in the Food Sector, Aarhus University. Haslegårdsvej \\ 10, 8210, Aarhus, Denmark.
}

\begin{abstract}
B. Schnettler, G. Crisóstomo, N. Mills, H. Miranda, M. Mora, G. Lobos and K.G. Grunert. 2013. Preferences for oil produced conventionally, produced with nanotechnology or genetically modified in the Araucanía Region of Chile. Cien. Inv. Agr. 40(1):17-29. In light of the increasing use of nanotechnology in food production, consumer acceptance of sunflower oil produced with nanotechnology or from genetically modified (GM) plants and the conventionally produced raw materials available in Temuco (Araucanía Region, Chile), market segments were differentiated with respect to their acceptance of nanotechnology and characterized according to their sociodemographic characteristics and food neophobia level. To achieve this aim, a survey was administered to 400 people. Using a conjoint analysis, the brand $(33.6 \%)$ and production system $(32.6 \%)$ were determined to be more important than the price $(19.2 \%)$ and health certification $(14.6 \%)$; national brands, produced conventionally with a health certification seal and sold at the lowest price, were preferred. A hierarchical cluster analysis identified three main segments. The largest $(45.5 \%)$ preferred oil made with nanotechnology. The second $(29.75 \%)$ preferred conventional oil and oil made with nanotechnology. The third $(20.75 \%)$ preferred conventional oil and rejected oils made with nanotechnology and GM. The segments differed significantly according to marital status and according to the score on the food neophobia scale. Approximately $75 \%$ of the sample had a positive response to the oil produced with nanotechnology, and this positive response was related to the food neophobia score.
\end{abstract}

Key words: sunflower oil, transgenic food, nanotechnology.

\section{Introduction}

The last two decades have seen considerable research and development efforts dedicated

Received July 21, 2012. Accepted December 11, 2012. Corresponding author: berta.schnettler@ufrontera.cl to new food technologies (Rollin et al., 2011). One of the reasons for such interest in new food technologies is the anticipated range of benefits they can bring to the consumer and the food sector. The reported advantages include the production of safer, healthier and more nutritious 
foods, the use of less energy, water and chemicals and the production of less waste. However, the toxicological nature of hazards, the likelihood of exposure to hazards and the risk to consumers posed by certain new food technologies are largely unknown (Chaudhry et al., 2008). Many factors can influence consumers' acceptance of food innovations. Understanding consumers' risk-benefit perceptions, sociodemographic attributes, knowledge and information, and trust in the source of information will be crucial to the realization and success of technological advances in food production (Frewer et al., 2011; Rollin et al., 2011; Eurobarometer, 2006). Public trust is imperative in the perception of new, unknown food technologies (Hosseini et al., 2012; Stampfli et al., 2010; Siegrist, 2008; Siegrist et al., 2007). Some authors indicate that the attitude to new technologies used in food production, e.g., genetic modification (GM) or nanotechnology, are related to food neophobia (Hosseini et al., 2012), or the reluctance to eat or the avoidance of new foods (Pliner and Hobden, 1992).

Public perceptions of GM technology have been the focus of considerable research. Typically, results suggest that GM agri-food technology is associated with high perceived risks and relatively low perceived benefits (Frewer et al., 2011). This is why numerous studies have reported a greater consumer preference for foods without GM and a rejection of transgenic foods (TF) (O'Brien et al., 2012; Bellows et al., 2010; Schnettler et al., 2010, 2008; Terawaki, 2008). However, there is also evidence of the existence of consumer groups with positive attitudes towards TF, but they are principally found in developing countries (De Steur et al., 2010; Kimenju and De Groote, 2008).

While no unified definition has been approved internationally, nanotechnology-enabled products can be broadly defined as being derived or issued from materials at scales measuring less than $100 \mathrm{~nm}$ in at least one dimension. At this scale, in part because of the larger surface/volume ratio, the physical, chemical and biological properties of materials can be fundamentally different from those of the corresponding bulk materials. In particular, nanomaterials often exhibit different thermodynamic, magnetic and optical properties than their bulk counterparts (Gruère, 2012). These unique properties have opened the door to the development of new applications in all sectors. In agriculture and food, a wide range of nanotechnological applications are being developed and commercialized with different goals ranging from improved food safety to reduced agricultural inputs, enhanced packaging and improved processing and nutrition (Miller, 2010); in addition, nanotechnology has the potential to promote sustainable agriculture and deliver better foods globally (Gruère 2012). Nanotechnology foods and food packaging are already being commercialized, though the number of available products is still low. In the near future, nanotechnology may become increasingly important in the food sector, with governmental agencies and industry investing considerable resources in its development and implementation (Frewer et al., 2011). Evidence suggests that most people are not, at present, familiar with nanotechnology (Hosseini et al., 2012; Siegrist, 2008; Cobb and Macoubrie, 2004). Early studies in the US and Canada found that nanotechnology was perceived by consumers in a more positive light (Priest, 2006; Cobb and Macoubrie, 2004), i.e., less risky and more beneficial than GM food products (Currall et al., 2006), although food-related applications are generally viewed less positively or differently than other applications (Siegrist et al., 2007). Studies conducted in developed countries indicate that consumers seem to be hesitant about buying nanotechnology foods (Bieberstein et al., 2012; Stampfli et al., 2010; Siegrist et al., 2009; Siegrist et al., 2008; Siegrist et al., 2007); however, evidence shows that there are differences among developed countries in this respect (Bieberstein et al., 2012). Consumers' attitudes towards nanotechnologybased food production are unknown in developing countries and South America. Therefore, the aims of this study were to compare the acceptance of sunflower oil produced with nanotechnology 
with the acceptance of genetically modified and conventionally produced foods among consumers in Temuco (Region of the Araucanía, Chile), to differentiate market segments according to their acceptance of nanotechnology and to characterize these segments according to their sociodemographic characteristics and level of food neophobia.

\section{Materials and methods}

\section{Survey}

A personal survey was administered in Temuco to a sample of 400 consumers over 18 years of age responsible for the purchase of food for their household. The number of respondents was obtained using the simple random sampling formula for nonfinite populations $(\mathrm{N}>100,000$; Temuco: 245,347 inhabitants according to the 2002 census), considering 95\% confidence and 5\% estimation error with $\mathrm{p}$ and q values of 0.5 (Fernández, 2002). A questionnaire with closed questions was used to determine whether the respondent had received information about nanotechnology and if they knew what it meant. The questionnaire included the Food Neophobia Scale (FNS), a psychometric instrument developed by Pliner and Hobden (1992) to measure food neophobia. Numerous studies have shown that the FNS accurately predicts responses to novel foods (Ritchey et al., 2003). The scale is composed of the following 10 items: 1 . I am constantly sampling new and different foods. 2 . I don't trust new foods. 3. If I don't know what a food is, I won't try it. 4. I like foods from different cultures. 5. Ethnic food looks too weird to eat. 6. At dinner parties, I will try new foods. 7. I am afraid to eat things I have never had before. 8. I am very particular about the foods I eat. 9. I will eat almost anything. 10. I like to try new ethnic restaurants. The respondents must indicate their degree of agreement with these statements using a 6-level Likert scale (1: disagree completely, 6: agree completely). Given that the psychometric properties of the FNS have not previously been studied in Chile, an exploratory factor analysis
(EFA) was used followed by a confirmatory factor analysis (CFA). The EFA was implemented using SPSS 16.0 (SPSS Inc., Chicago, USA), and the CFA was implemented using LISREL 8.8 (Scientific Software International, Inc. Chicago, USA). The parameters in the CFA were estimated by robust maximum likelihood (Hair et al., 1999). The results of the EFA revealed that only one factor grouped six of the ten original items $(65.3 \%$ explained variance). Items 2, 3, 8 and 9 were eliminated because they presented communality values below 0.4 . For the six remaining items, the FNS presented a suitable level of internal consistency (Cronbach's $\alpha: 0.892)$. A CFA model fits reasonably well if the Chi-Square $\left(\chi^{2}\right)$ is not significant, if the goodnessof-fit index (GFI) and the adjusted goodness-of-fit index (AGFI) are greater than 0.90 , and if the root mean square error of approximation (RMSEA) is lower than 0.08 ( $\mathrm{Hu}$ and Bentler, 1999). The CFA performed with the six items of the FNS meant that the one-dimensional structure of the FNS could be validated with a good goodnessof-fit (Chi-Square=7.5, P-value=0.186, RMSEA= $0.035, \mathrm{GFI}=0.99, \mathrm{AGFI}=0.97)$. The standardized factor loadings for the six items were statistically significant; therefore, it may be concluded that there was convergent validity. If the FNS is formed of a single factor, then the food neophobia index is obtained by adding the points scored from the items on the scale; the higher the score, the higher the value obtained from the total (Pliner and Hobden, 1992).

These classification questions were included: gender, age, marital status, size of family group, area of residence, occupation and studies of the head of the household, and the possession of ten domestic goods. These two last variables help determine the socioeconomic group, which was classified as $\mathrm{ABC} 1$ (high and middle-high), $\mathrm{C} 2$ (middle-middle), C3 (lower-middle), D (low) and E (very low) (Anónimo, 2004). The survey was applied in three supermarkets in Temuco between April and July of 2011 after the questionnaire had been validated by means of a preliminary test with $10 \%$ of the sample. 


\section{Statistical analysis}

A conjoint analysis (CA) was employed to determine the acceptance of sunflower oil produced with nanotechnology, with GM plants or conventionally. A CA is a decompositional method that allows the relative importance of the attributes of a product and the part worth utility values for each level of an attribute to be estimated. The estimated part worth utility indicates how influential each level of an attribute is in the formation of consumer preferences for a particular combination, i.e., the degree of preference for each level of an attribute (Hair et al., 1999). Table 1 shows the attributes and levels defined in the study. The attributes brand (Banović et al., 2010; Finucane and Holup, 2005; Verdume and Viaene, 2003), health certification (Frewer et al., 2011; Rollin et al., 2011) and price (Banović et al., 2010) were included, as these are quality indicators that help reduce uncertainty and the perception of risk when purchasing food. The levels established for the attribute "brand" correspond to two manufacturers' brands (one domestic and one imported from Argentina) and a store brand from one of the main supermarket chains in Chile. For the attribute "production technology", the levels "conventional", "produced with GM raw materials" and "produced with nanotechnology" were defined. The price levels were established on the basis of the lowest, highest and average prices of the brands of oil chosen for the survey. For the attribute "health certification seal", the levels "without seal", "with seal from the Chilean Servicio Agrícola y Ganadero (SAG)" were used. From these attributes and levels, a total of 54 combinations $(3 \times 3 \times 3 \times 2)$ were obtained; however, a fractional factorial design was used, employing the orthoplan option of SPSS 16.0 (Hair et al., 1999). This allowed the number of stimuli to be reduced to twelve with one specification for each attribute. Each respondent ordered the cards with the combination of attributes from most to least preferred, on a scale of 1 to 12 (1 $=$ most preferred; 12 = least preferred). Two of these cards were used as holdout cases. Prior to asking the respondents to put the cards in order, the definition used by Siegrist et al. (2008) was read to them: "Nanotechnology is considered one of the key revolutionizing technologies of the 21st century and refers to a broad range of advanced applications that deal with particles and structures smaller than $100 \mathrm{~nm}$. One nanometer is one billionth of a meter. The breadth of possible fields of application is far-reaching and includes, for example, energy and information technologies as well as the medical and cosmetics industries. In the near future, the food industry plans to realize the potentials of nanotechnology to extend shelf life, customize flavors, or improve human health and well-being. Along with the beneficial aspects, nanotechnology also carries possible risks that we know little about. The biggest worry among experts is that nanoparticles may permeate the human body. The effects of nanoparticles on human health and the environment are still widely unknown". In addition, the respondents received the following definition of a GM food: "Genetically modified foods are those that have artificially received a foreign gene at the embryonic stage; so when they reproduce, they maintain this new characteristic, for example, to eliminate the use of pesticides, fungicides or herbicides during cultivation".

Conjoint analysis was carried out by means of the TRANSREG procedure of SAS 9.3 (SAS Institute Inc., Cary, NC, USA). The relative importance that consumers gave to the different attributes and the utility values obtained for each level of the selected factors were determined. The Root Mean Square Error (RMSE) was calculated to measure the difference between the observed and the predicted data. In addition, the market share of the possible products that could share the market was simulated. The market share simulation was carried out using the maximum utility model (Kuhfeld, 2010).

A hierarchical cluster analysis was chosen to determine consumer segments according to the importance of the attributes and partial utility scores of the levels of the attributes. Ward's procedure, 
Table 1. Design of the conjoint experiment.

\begin{tabular}{lllll}
\hline Card & Brand & Production Technology & $\begin{array}{l}\text { Price (US\$ } \\
\mathrm{L}^{-1} \text { ) }\end{array}$ & Health certification seal \\
\hline A & Chef & Oil produced with GM raw materials & 2.5 & No seal \\
B & Chef & Oil produced with nanotechnology & 2.7 & SAG seal \\
C & Chef & Oil produced with GM raw materials & 3.2 & SAG seal \\
D & Chef & Oil produced with nanotechnology & 3.2 & No seal \\
E & Natura & Oil produced conventionally & 3.2 & No seal \\
F & Natura & Oil produced with nanotechnology & 2.7 & SAG seal \\
G & Natura & Oil produced with GM raw materials & 2.5 & No seal \\
H & Natura & Oil produced with nanotechnology & 2.5 & SAG seal \\
I & Natura & Oil produced with nanotechnology & 2.7 & No seal \\
J & Jumbo & Oil produced with GM raw materials & 3.2 & SAG seal \\
K & Jumbo & Oil produced conventionally & 2.7 & No seal \\
L & Jumbo & Oil produced with nanotechnology & 3.2 & No seal \\
\hline
\end{tabular}

GM: genetically modified. SAG: Servicio Agrícola y Ganadero (Chile).

The national currency values (Chilean pesos) were converted to dollars using the average 2011 value (\$483.67/US\$).

which calculates the squared Euclidean distance, was carried out with the CLUSTER procedure of SAS. The number of clusters was taken on the basis of the $\mathrm{R}^{2}$ obtained and from a strong increase produced in the Cubic Criterion of Clustering and Pseudo-F values. To describe the segments, a Pearson Chi-square $\left(\chi^{2}\right)$ test was applied for the discrete variables and a one-factor analysis of variance was applied for the continuous variables (99\% and 95\% confidence level). Because Levene's test indicated non-homogenous variances, the averages of variables with significant differences ( $\mathrm{P} \leq 0.001$ or $\mathrm{P} \leq 0.05$ ) were separated according to Dunnett's T3 test for multiple comparisons.

\section{Results}

In the sample of consumers surveyed, there were more women, people between 35 and 54 years of age, married people or those living with a partner, people from families with three to four members, urban residents, employees, and people from socioeconomic group $\mathrm{ABC} 1$. The majority of respondents indicated that they had not received any information on nanotechnology and did not know its meaning (Table 2).

\section{Importance of the attributes and preferences}

Using a conjoint analysis, it was established that in the total sample, the attributes of greatest importance in the purchase of oil were the brand and the production technology, followed by the price and finally the presence of a health certification seal. The signs of the preference values of the attribute levels indicated a preference for oil with manufacturer brands (greatest preference for the Chef brand) and a rejection of the store brand. In addition, the respondents preferred the conventionally produced oil and rejected the oil produced from raw materials with GM and with nanotechnology. Likewise, preference was observed for the product with the SAG seal and the lowest price. The RMSE of the conjoint analysis was 0.22 (Table 3 ). The average of the sum of the items from the FNS in the total sample was 17.50 (range $=6-36 ; \mathrm{SD}=6.62$ ).

\section{Consumer segments}

A cluster analysis significantly distinguished $(\mathrm{P} \leq 0.05)$ four consumer groups in terms of the importance of and preference for the brand of 
Table 2. Description in percentages of the sample of habitual supermarket consumers in Temuco, Chile. July, 2011.

\begin{tabular}{|c|c|c|}
\hline Sample & Composition & Total sample $(\mathrm{n}=400) \%$ \\
\hline \multirow[t]{2}{*}{ Gender } & Female & 64.5 \\
\hline & Male & 35.5 \\
\hline \multirow[t]{2}{*}{ Marital status } & Single, separated, divorced or widowed & 35.5 \\
\hline & Married or cohabiting & 64.5 \\
\hline \multirow[t]{3}{*}{ Age } & $<35$ years & 23.8 \\
\hline & $35-54$ years & 50.2 \\
\hline & 55 years or more & 26.0 \\
\hline \multirow[t]{3}{*}{ Family size } & 1-2 family members & 26.3 \\
\hline & 3-4 family members & 59.5 \\
\hline & 5 or more & 14.2 \\
\hline \multirow[t]{2}{*}{ Residence } & Urban & 95.8 \\
\hline & Rural & 4.2 \\
\hline \multirow[t]{7}{*}{ Occupation } & Self-employed & 7.2 \\
\hline & Entrepreneur & 11.8 \\
\hline & Employee & 51.0 \\
\hline & Public employee & 17.2 \\
\hline & Retired & 12.0 \\
\hline & Unemployed & 0.3 \\
\hline & Other situation & 0.5 \\
\hline \multirow[t]{4}{*}{ Socioeconomic group } & $\mathrm{ABCl}$ (high and middle-high) & 41.0 \\
\hline & C2 (middle-middle) & 25.3 \\
\hline & C3 (middle-lower) & 23.5 \\
\hline & $\mathrm{D}$ (lower) & 10.2 \\
\hline \multirow[t]{2}{*}{ Have received information regarding nanotechnology } & Yes & 31.2 \\
\hline & No & 68.8 \\
\hline \multirow[t]{2}{*}{ Know the meaning of nanotechnology } & Yes & 27.5 \\
\hline & No & 72.5 \\
\hline
\end{tabular}

oil, the production technology, the presence of a health certification seal and the price (Table 3). The groups differed significantly by FNS scores (Table 3 ) and marital status $(\mathrm{P} \leq 0.05)$ (Table 4$)$. No differences were observed in gender, age, family size, residence, occupation or socioeconomic group, according to whether the consumers had received information regarding nanotechnology or whether they knew the meaning of nanotechnology $(\mathrm{P}>0.1)$.

Group $1(n=182)$ represented $45.5 \%$ of the survey sample and gave the greatest importance (significantly more than other groups) to the brand (43.0\%). The people in this group preferred manufacturer brands significantly more than people from Groups 3 and 4. The negative preference value towards the store brand was significantly lower than in Groups 3 and 4, which indicates a greater rejection in Group 1. The second most important attribute for this Group was the production technology, though the importance was significantly lower than that reported for Group 3. Group 1 stood out as being the only group that rejected conventional oil. The preference for oil produced with nanotechnology was significantly higher than in Groups 3 and 4. This group was the only one that preferred to pay the highest price. The average FNS score in Group 1 was similar to that of Group 2 and significantly lower than that of Group 3 (Table 
Table 3. Distribution and relative importance of the three clusters and overall sample based on preferences for sunflower oil produced conventionally, produced with nanotechnology or genetically modified, and the sum score of the Food Neophobia Scale.

\begin{tabular}{|c|c|c|c|c|c|c|c|}
\hline Attribute and levels & $\begin{array}{l}\text { Total sample } \\
(\mathrm{n}=400)\end{array}$ & $\begin{array}{l}\text { Group 1 } \\
(\mathrm{n}=182)\end{array}$ & $\begin{array}{l}\text { Group 2 } \\
(\mathrm{n}=119)\end{array}$ & $\begin{array}{l}\text { Group } 3 \\
(\mathrm{n}=83)\end{array}$ & $\begin{array}{l}\text { Group } 4 \\
(\mathrm{n}=16)\end{array}$ & $\mathrm{F}$ & $\mathrm{p}$ \\
\hline \multicolumn{8}{|l|}{ Brand: } \\
\hline Chef & 1.280 & $1.459 \mathrm{a}$ & $1.525 \mathrm{a}$ & $0.674 \mathrm{~b}$ & $0.591 \mathrm{~b}$ & 7.401 & $\leq 0.001$ \\
\hline Natura & 0.829 & $1.125 \mathrm{a}$ & $0.878 \mathrm{a}$ & $0.239 \mathrm{~b}$ & $0.209 \mathrm{~b}$ & 8.087 & $\leq 0.001$ \\
\hline Jumbo & -2.103 & $-2.578 b$ & $-2.397 b$ & $-0.907 \mathrm{a}$ & $-0.795 \mathrm{a}$ & 39.930 & $\leq 0.001$ \\
\hline Relative importance (\%) & 33.6 & $43.0 \mathrm{a}$ & $32.6 \mathrm{~b}$ & $17.4 \mathrm{c}$ & $20.0 \mathrm{c}$ & 80.416 & $\leq 0.001$ \\
\hline \multicolumn{8}{|l|}{ Production Technology } \\
\hline Conventional & 1.037 & $-0.148 \mathrm{c}$ & $0.962 \mathrm{~b}$ & $3.890 \mathrm{a}$ & $0.112 \mathrm{c}$ & 119.337 & $\leq 0.001$ \\
\hline Genetically modified & -0.578 & $-0.134 b$ & $-1.019 \mathrm{c}$ & $-1.102 \mathrm{c}$ & $0.430 \mathrm{a}$ & 8.586 & $\leq 0.001$ \\
\hline Produced with nanotechnology & -0.455 & $0.286 \mathrm{a}$ & $0.062 \mathrm{a}$ & $-2.786 c$ & $-0.539 \mathrm{~b}$ & 65.844 & $\leq 0.001$ \\
\hline Relative importance (\%) & 32.6 & $28.7 \mathrm{~b}$ & $24.4 \mathrm{~b}$ & $56.3 \mathrm{a}$ & $15.3 \mathrm{c}$ & 126.741 & $\leq 0.001$ \\
\hline \multicolumn{8}{|l|}{ Health certification seal } \\
\hline No seal & -0.876 & $-0.366 \mathrm{a}$ & $-1.769 \mathrm{c}$ & $-0.833 b$ & $-0.193 \mathrm{a}$ & 89.332 & $\leq 0.001$ \\
\hline SAG seal & 0.876 & $0.366 \mathrm{c}$ & $1.769 \mathrm{a}$ & $0.833 \mathrm{~b}$ & $0.193 \mathrm{c}$ & 89.332 & $\leq 0.001$ \\
\hline Relative importance (\%) & 14.6 & $9.6 \mathrm{~b}$ & $25.1 \mathrm{a}$ & $11.8 \mathrm{~b}$ & $6.1 \mathrm{~b}$ & 72.260 & $\leq 0.001$ \\
\hline \multicolumn{8}{|l|}{ Price } \\
\hline $\mathrm{US} \$ 2.5 \mathrm{~L}^{-1}$ & 0.503 & $0.024 \mathrm{c}$ & $0.769 \mathrm{~b}$ & $0.654 \mathrm{~b}$ & $3.134 \mathrm{a}$ & 30.995 & $\leq 0.001$ \\
\hline US\$ $2.7 \mathrm{~L}^{-1}$ & -0.376 & $-0.223 b$ & $-0.864 \mathrm{c}$ & $-0.209 \mathrm{~b}$ & $0.673 \mathrm{a}$ & 17.744 & $\leq 0.001$ \\
\hline US\$ $3.2 \mathrm{~L}^{-1}$ & -0.803 & $0.203 \mathrm{a}$ & $0.099 \mathrm{ab}$ & $-0.441 b$ & $-3.803 \mathrm{c}$ & 58.876 & $\leq 0.001$ \\
\hline Relative importance (\%) & 19.2 & $18.7 \mathrm{~b}$ & $17.9 \mathrm{~b}$ & $14.5 \mathrm{~b}$ & $58.6 \mathrm{a}$ & 80.476 & $\leq 0.001$ \\
\hline FNS score & 17.50 & $17.11 \mathrm{~b}$ & $17.11 \mathrm{~b}$ & $19.61 \mathrm{a}$ & $14.06 \mathrm{c}$ & 4.636 & $\leq 0.05$ \\
\hline
\end{tabular}

Root-mean-square error $(\mathrm{RMSE})=0.22$.

Utility numbers in the different levels from an attribute with a negative sign indicate utility loss for the consumer.

Different letters in the line indicate significant differences according to Dunnett's T3 multiple comparison test $(\mathrm{P} \leq 0.05)$.

The national currency values (Chilean pesos) were converted to dollars using the average 2011 value (\$483.67/US\$).

Table 4. Characteristics with significant differences in the groups of buyers identified by cluster analysis.

\begin{tabular}{lcccc}
\hline Characteristic & $\begin{array}{l}\text { Group 1 } \\
(\mathrm{n}=182)\end{array}$ & $\begin{array}{l}\text { Group 2 } \\
(\mathrm{n}=119)\end{array}$ & $\begin{array}{l}\text { Group 3 } \\
(\mathrm{n}=83)\end{array}$ & $\begin{array}{l}\text { Group 4 } \\
(\mathrm{n}=16)\end{array}$ \\
\hline Marital status & $\mathrm{P}=0.007$ & & & \\
Single, separated, divorced or widowed & 29.4 & 35.3 & 42.2 & 68.8 \\
Married or cohabiting & 70.6 & 64.7 & 57.8 & 31.2 \\
\hline
\end{tabular}

P value corresponds to the (bilateral) asymptotic significance obtained in Pearson's Chi-squared Test.

3). Group 1 presented the greatest proportion of married people or those living with a partner (70.6\%) (Table 4). Group 1 can be classified as "Consumers sensitive to brand who prefer oil produced with nanotechnology".
Group $2(n=119)$ represented $29.75 \%$ of the sample. Although the most relevant attribute for this group was the brand, the group valued the presence of a health certification seal (particularly the SAG seal), significantly more than the other 
groups. The relative importance of production technology was similar to that of the health certification seal: people in this group preferred the conventionally produced oil and the oil produced with nanotechnology (Table 3). In accordance with these results, Group 2 can be called "Consumers sensitive to both the brand and the health certification seal who prefer oil produced with nanotechnology and conventionally produced oil".

Group $3(n=83)$ represented $20.75 \%$ of the sample and assigned greatest importance to the technology used for oil production (56.3\%), significantly more than the other groups. The people in this group showed the greatest preference for the conventional product, significantly more than the other groups. Likewise, this group presented a significantly more negative preference value for oil produced with nanotechnology than the other groups, indicating the greatest rejection. This group strongly rejected oil produced with GM plants, although this rejection did not differ significantly from that of Group 2. The score obtained on the FNS was significantly higher in Group 3 than in the other groups (Table 3). With these results, this group can be called "Neophobic consumers who reject nanotechnology and GM".

Group $4(n=16)$ represented only $4.0 \%$ of the sample and assigned a significantly higher importance to the price than the other groups. Consistent with this preference was evidence of a strong rejection of the highest priced product. Group 4 stands out as being the only group that preferred GM oil. As with the previous group, this group preferred the conventional oil and rejected the product made with nanotechnology (Table 3). Group 4 presented the largest proportion of single, separated, widowed or divorced people (68.8\%) (Table 4). Group 4 can be called "Consumers sensitive to price who prefer GM and conventional oil".

Regardless of the importance assigned to the production technology and attitude towards nanotechnology, all four groups preferred the manufacturers' brands, rejected the store brand and preferred the product with a SAG seal.

Table 5 presents the results of the market share simulation, representing a total accumulation of $66 \%$. The largest market share (17.3\%) was for the Chef brand of oil, produced conventionally at the lowest price with the SAG seal. The next largest share (10.5\%) was for the Natura brand of oil, produced conventionally at the lowest price with the SAG seal. All of the most preferred oils had the SAG seal and a manufacturer's brand. Five of the most preferred oils were of the Chef brand, produced conventionally at the lowest price. It should be emphasized that the market participation of conventionally produced oil reached $49.2 \%$, while the other preferred alternatives are presented in Table 5.

\section{Discussion}

The results of this study confirmed the paucity of people with knowledge of nanotechnology, as approximately $70 \%$ of respondents had had no previous information on nanotechnology or knew its meaning; this proportion is similar to proportions observed in developed countries (Hosseini et al., 2012; Siegrist, 2008; Cobb and Macoubrie, 2004).

Using a conjoint analysis, the attributes "brand" and "production technology" were determined to be more important than the price and existence of a health certification seal in the decision to purchase oil in Temuco. Four consumer segments were established based on the importance assigned to the attributes studied and on the preference for sunflower oil made with nanotechnology. Because the number of consumers in Group 4 ( $n=$ 16) was so low, a decision was made not to draw any conclusions from this group, as doing so may have been risky (McEwan, 1997). In this context, in contrast to the reports from previous studies in developed countries (Bieberstein et al., 2012; Stampfli et al., 2010; Siegrist et al., 2009; Siegrist 
Table 5. Sunflower oil expected market share (Maximum utility model).

\begin{tabular}{llccc}
\hline \multirow{2}{*}{ Brand } & Production Technology & $\begin{array}{l}\text { Price } \\
\left(\text { US } \$ \mathrm{~L}^{-1}\right)\end{array}$ & Health certification seal & $\begin{array}{c}\text { Market share } \\
(\%)\end{array}$ \\
\hline Chef & Oil produced conventionally & 2.5 & SAG seal & 17.3 \\
Natura & Oil produced conventionally & 2.5 & SAG seal & 10.5 \\
Chef & Oil produced conventionally & 2.7 & SAG seal & 7.8 \\
Natura & Oil produced conventionally & 3.2 & SAG seal & 7.8 \\
Chef & Oil produced conventionally & 3.2 & SAG seal & 5.8 \\
Chef & Oil produced with nanotechnology & 2.5 & SAG seal & 5.3 \\
Natura & Oil produced with nanotechnology & 2.5 & SAG seal & 5.0 \\
Natura & Oil produced with nanotechnology & 3.2 & SAG seal & 3.5 \\
Chef & Oil produced with nanotechnology & 3.2 & SAG seal & 3.0
\end{tabular}

SAG: Servicio Agrícola y Ganadero (Chile).

et al., 2008; Siegrist et al., 2007), two consumer segments (Groups 1 and 2; 75.3\%) preferred the oil produced with nanotechnology. This result and the rejection of GM oil in Groups 1,2 and 3 is consistent with studies conducted in North America that indicated a greater acceptance of nanotechnology than GM (Currall et al., 2006; Priest, 2006; Cobb and Macoubrie, 2004); this preference might be related to the perception of GM by many people as unnatural (Stampfli et al., 2010). Likewise, the rejection of GM oil confirms the results from previous studies conducted both in developed countries (O'Brien et al., 2012; Bellows et al., 2010; Terawaki, 2008) and in Chile (Schnettler et al., 2010, 2008) that reported a greater consumer preference for foods without GM and a rejection of TF. Because the acceptance of foods produced with new technologies is directly associated with consumers' perception of the risks and benefits of the associated technology (Frewer et al., 2011; Rollin et al., 2011; Siegrist et al., 2008; Siegrist et al., 2007), these results suggest that the participants perceived GM products as riskier than those produced with nanotechnology; furthermore, this perception occurred despite the fact that a definition of nanotechnology, which included the potential benefits and risks associated with its use, was given before presenting the stimuli of the conjoint analysis. This suggests that the respondents accorded greater importance to the possible benefits associated with nanotechnology than to the as yet little-known possible risks because a large part of the sample (Group 1; 45.5\%) preferred the oil produced with nanotechnology to the conventionally produced oil. This finding contradicts Siegrist (2008) who reported that consumers, possibly perceiving new food technologies as riskier than traditional food technologies, preferred traditionally produced foods. It must be noted that in this study, this preference was only observed in Group 3 (20.75\%), which gave greatest importance to the attribute related to production technology. Importantly, this group obtained significantly higher scores on the FNS than Groups 1 and 2, which justifies the conclusion that the level of food neophobia in consumers is related to the rejection of GM and nanotechnology use in food production, a finding consistent with results of Hosseini et al. (2012). The results obtained corroborate the fact that neophobics make more negative evaluations when confronted with unfamiliar foods than neophilics (Siegrist, 2008). However, given that the FNS scores of the four groups were close to the average of the scale (17.50) and far from the theoretical maximum score (36), it is possible to suggest that the sample studied possesses an average level of neophobia. It can therefore be expected that the introduction of novel foods in the market would not be significantly affected by the level of consumer neophobia.

The generalized preference for manufacturers' brands and the rejection of the store brand is in 
agreement with the results from a previous study in Chile in which consumer acceptance of TF of plant and animal origin was evaluated (Schnettler et al., 2008). This indicates that the brand helps reduce uncertainty and the perception of risk when purchasing foods produced with new technologies such as GM and nanotechnology. The results of this investigation suggest that consumers used the SAG seal to reduce their perception of the risk associated with the purchased product. Both results confirm the importance of public trust in the perception of new, unknown novel food technologies (Hosseini et al., 2012; Stampfli et al., 2010; Siegrist, 2008; Siegrist et al., 2007), as the consumers preferred the product with the recognized brand guaranteed by the SAG. Consumer confidence in the food industry and in government regulations therefore plays an important role in the acceptance of new technologies applied to food production (Siegrist, 2008). The price of the product may also be used to reduce the perceived risk of the product. However, this behavior was only observed in Group 1 (45.5\%), which showed greater preference for the highest price. Groups 2 and $3(50.5 \%)$ preferred the lowest price, indicating that there was no perceived association between price and quality, a finding in line with the results of previous studies conducted in Chile (Schnettler et al., 2010, 2008).

In terms of sociodemographics, differences were detected in marital status among the segments identified. This finding disagrees with the results of research conducted in developed countries that found gender- and age-associated differences in the acceptance of nanotechnology (Siegrist et al., 2008; Eurobarometer, 2006).

The results of the conjoint analysis in the total sample studied in Temuco indicate a preference for conventionally produced oil. At the same time, the results of the cluster analysis reveal the existence of consumer segments that are positive about the possibility of buying oil produced with nanotechnology, which is good news for the introduction of food produced with nanotechnology onto the domestic market. However, at the product level, any commercial strategy to introduce foods produced with nanotechnology into the Chilean market would have to consider the support of widely recognized manufacturers' brands that inspire confidence. In the area of promotion, consumers must be informed of the risks and benefits associated with nanotechnology, as the public appreciates receiving information that can facilitate the decision to buy traditionally produced foods or foods produced with new technologies (Napier et al., 2004). Therefore, the norms for food labelling in Chile would need to contemplate the inclusion of information on the form of production, clearly indicating whether the food was produced with nanotechnology. At the same time, the competent authorities of the Chilean government (Ministry of Health, Ministry of Agriculture) would have to provide consumers with truthful and reliable information regarding the risks and benefits associated with nanotechnologically produced food to make the trade in these products transparent.

Finally, considering that the acceptance of nanotechnology (Siegrist et al., 2008) and GM (Schnettler et al., 2010) depends on the specific application of these technologies, new research is required in Chile to further understand this topic.

\section{Acknowledgements}

Study financed by FONDECYT, project 1100611. 


\title{
Resumen
}

\begin{abstract}
B. Schnettler, G. Crisóstomo, N. Mills, H. Miranda, M. Mora, G. Lobos y K.G. Grunert. 2013. Preferencias hacia aceite producido en forma convencional, con nanotecnología y genéticamente modificado en la Región de La Araucanía, Chile. Cien. Inv. Agr. 40(1):1729. Considerando el creciente uso de la nanotecnología en la producción de alimentos, se evaluó la aceptación de aceite de maravilla producido con nanotecnología, con materias primas genéticamente modificadas (GM) y producido convencionalmente en consumidores de Temuco (Región de La Araucanía, Chile), se diferenciaron segmentos de mercado en relación con la aceptación hacia la nanotecnología y, se caracterizaron según sus características sociodemográficas y nivel de neofobia alimentaria, mediante una encuesta a 400 personas. Utilizando análisis conjunto se determinó que la marca $(33,6 \%)$ y el sistema de producción $(32,6 \%)$ fueron más importantes que el precio $(19,2 \%)$ y una certificación sanitaria $(14,6 \%)$, con preferencia hacia el aceite con marcas nacionales, producido convencionalmente, con sello de certificación sanitaria, al menor precio. Mediante análisis de conglomerados jerárquicos se diferenciaron tres segmentos principales. El mayoritario (45,5\%) prefirió el aceite producido con nanotecnología. El segundo (29,75\%) prefirió el aceite convencional y con nanotecnología. El tercero $(20,75 \%)$ prefirió el aceite convencional y presentó alto rechazo hacia los aceites con nanotecnología y GM. Los segmentos se diferenciaron significativamente según estado civil y en los puntajes de la escala de neofobia alimentaria. Aproximadamente el $75 \%$ de la muestra tuvo una respuesta positiva hacia el aceite producido con nanotecnología, lo que se relaciona con el nivel de neofobia alimentaria.
\end{abstract}

Palabras clave: Aceite de maravilla, alimentos transgénicos, nanotecnología.

\section{References}

Anónimo. 2004. Mapa Socioeconómico de Chile. Adimark, Investigación de Mercados y Opinión Pública. Santiago, Chile. Available online at: www.adimark.cl (Website accessed: April, 2005).

Banović, M., K.G. Grunert, M. Barreira, and M. Fontes. 2010. Consumers' quality perception of national branded, national store branded, and imported store branded beef. Meat Science 84:54-65

Bellows, A., G. Alcaraz, and W. Hallman. 2010. Gender and food, a study of attitudes in the USA towards organic, local, U.S. grown, and GM-free foods. Appetite 55:540-550.

Bieberstein, A., J. Roosen, S. Marette, S. Blanchemanche, and F. Vandermoere. 2012. Consumer choices for nano-food and nanopackaging in France and Germany. European Review of Agricultural Economics p. 1-22. doi:10.1093/erae/jbr069.
Chaudhry, Q., M. Scotter, J. Blackburn, B. Ross, A. Boxall, L. Castle, R. Aitken, and R. Watkins. 2008. Applications and implications of nanotechnologies for the food sector. Food Additives and Contaminants 25:241-258.

Cobb, M., and Macoubrie, A. 2004. Public perceptions about nanotechnology: risks, benefits and trust. Journal of Nanoparticle Research 6:395-405.

Currall, S., E. King, N. Lane, J. Madera, and S. Turner. 2006. What drives public acceptance of nanotechnology? Nature Nanotechnology 1:153-155.

De Steur, H., X. Gellynck, S. Storozhenko, G. Liqun, W. Lambert, D. Van Der Straeten, and J. Viaene. 2010. Willingness-to-accept and purchase genetically modified rice with high folate content in Shanxi Province, China. Appetite 54:118-125.

Eurobarometer. 2006. Risk issues. Special eurobarometer 238/Wave 64.1. Brussels: TNS Opinion \& Social. February 2006.

Fernández, A. 2002. Investigación y Técnicas de Mercado. Editorial Esic. Madrid, España. 273 pp. 
Finucane, M.L., and J.L. Holup. 2005. Psychological and cultural factors affecting the perceived risk of genetically modified food: an overview of the literature. Social Science and Medicine 60:1603-1612.

Frewer, L.J., K. Bergmann, M. Brennan, R. Lion, R. Meertens, G. Rowe, M. Siegrist, and C. Vereijken. 2011. Consumer response to novel agri-food technologies: Implications for predicting consumer acceptance of emerging food technologies. Trends in Food Science \& Technology 22: 442-456.

Gruère, G. 2012. Implications of nanotechnology growth in food and agriculture in OECD countries. Food Policy 37:191-198.

Hair, J., R. Anderson, R. Tatham y W. Black. 1999. Análisis Multivariante. Quinta edición. Prentice Hall Internacional, Inc. Madrid, España. 832 pp. Hosseini, A., E. Goddard, F. Vandermoere, S. Blanchemanche, A. Bieberstein, S. Marette, and J. Roosen. 2012. Do environmental attitudes and food technology neophobia affect perceptions of the benefits of nanotechnology? International Journal of Consumer Studies 36:149-157.

Hu, L., and P. Bentler. 1999. Cutoff criteria for fit indexes in covariance structure analysis: Conventional criteria versus new alternatives. Structural Equation Modeling 6:1-55.

Kimenju, S., and H. De Groote. 2008. Consumer willingness to pay for genetically modified food in Kenya. Agricultural Economics 38:35-46.

Kuhfeld, W. 2010. Marketing research methods in SAS. Experimental design, choice, conjoint and Graphical techniques. SAS 9.2 Edition. Available online at: http://support.sas.com/techsup/technote/ mr2010.pdf (Website accessed: November, 2012).

McEwan, J.A. 1997. A comparative study of three product acceptability trials. Food Quality and Preference 8:183-190.

Miller, D.D. 2010. Food nanotechnology: new leverage against iron deficiency. Nature Nanotechnology 5:318-319.

Napier, T., M. Tucker, C. Henry and S. Whaley. 2004. Consumer attitudes toward GMOs: the Ohio experience. Journal of Food Science 69:69-76.

O'Brien, G., B. Stewart-Knox, A. McKinley, M. Vaz de Almeida, and M. Gibney. 2012. Perceived risk of metabolic syndrome and attitudes towards fat-modified food concepts among European consumers. Food Quality and Preference 23:79-85.

Pliner, P., and K. Hobden. 1992. Development of a scale to measure the trait of food neophobia in humans. Appetite 19:105-120.

Priest, S. 2006. The North American opinion climate for nanotechnology and its products: opportunities and challenges. Journal of Nanoparticle Research 8:563-568.

Ritchey, P., R. Frank, U. Hurstic, and H. Tuorila. 2003. Validation and cross-national comparison of the food neophobia scale (FNS) using confirmatory factor analysis. Appetite 40:163-173.

Rollin, F., J. Kennedy, and J. Wills. 2011. Consumers and new food technologies. Trends in Food Science \& Technology 22:99-111.

Schnettler, B., O. Sepúlveda, and D. Ruiz. 2008. Aceptación diferenciada de alimentos transgénicos de origen vegetal y animal en la Región de La Araucanía, Chile. Ciencia e Investigación Agraria 35:169-180

Schnettler, B., A. González, R. Avila, H. Miranda, J. Sepúlveda, and M. Denegri. 2010. Preference for oils with different types of genetic modifications in Temuco, Araucanía Region, Chile. Ciencia e Investigación Agraria 37:17-28.

Siegrist, M., M. Cousin, H. Kastenholz, and K. Wiek. 2007. Public acceptance of nanotechnology foods and food packaging: the influence of affect and trust. Appetite 49:459-466.

Siegrist, M. 2008. Factors influencing public acceptance of innovative food technologies and products: food innovation management. Trends in Food Science \& Technology 19:603-608.

Siegrist, M., N. Stampfli, H. Kastenholz, and C. Keller. 2008. Perceived risks and perceived benefits of different nanotechnology foods and nanotechnology food packaging. Appetite 51:283-290.

Siegrist, M., N. Stampfli, and H. Kastenholz. 2009. Acceptance of nanotechnology foods: a conjoint study examining consumers' willingness to buy. British Food Journal 111:660-668.

Stampfli, N., M. Siegrist, and H. Kastenholz. 2010. Acceptance of nanotechnology in food and food 
packaging: a path model analysis. Journal of Risk Research 13:353-365.

Terawaki, T. 2008. Can information about genetically modified corn and its oil have significant effects on Japanese consumers' risk perception and their valuation? AgBioForum 11:39-47.
Verdume, A. and J. Viaene. 2003. Consumer beliefs and attitude towards genetically modified food: basis for segmentation and implications for communication. Agribusiness 19:91-113. 
